\title{
UPAYA MENINGKATKAN AKTIVITAS DAN HASIL BELAJAR SISWA PADA MATERI PANCASILA SEBAGAI IDEOLOGI TERBUKA DENGAN MENGGUNAKAN PENDEKATAN CONTEXTUAL TEACHING AND LEARNING (CTL) DI KELAS XII IPA.1 SMA NEGERI 1 LAWA TAHUN PELAJARAN 2016/2017
}

\author{
oleh \\ LA MBUNI \\ Guru SMAN 1 Lawa, Kabupaten Muna Barat \\ Email: 1ambuni@gmail.com
}

\begin{abstract}
ABSTRAK
Penelitian ini bertujuan untuk: 1) untuk meningkatkan aktivitas belajar siswa pada materi pancasila idiologi terbuka di kelas XII IPA 1 SMA Negeri 1 Lawa tahun pelajaran 2016/2017, dan 2) untuk meningkatkan hasil belajar PKN pada materi pancasila sebagai idiologi terbuka di kelas XII IPA 1 SMA Negeri 1 Lawa tahun ajaran 2016/2017. Jenis penelitian ini adalah penelitian tindakan kelas (classroom action research). Penerapan penelitian tindakan di dalam kelas diharapakan akan mampu mendorong guru untuk memiliki kesadaran diri melakukan refleksi dan kritik diri terhadap aktivitas pembelajaran yang diselenggarakan. Penelitian ini dilaksanakan sebanyak dua siklus terdiri atas perencanaan,pelaksanaan, pengamatan, dan refleksi. Pelaksanaan tiap siklus akan diambil satu kelas yang sama. Hal ini ditempuh untuk membandingkan dan menggambarkan proses pembelajaran pada tiap-tiap siklus. Penelitianinidilaksanakan pada semester ganjil tahun pelajaran 2016-2017 di kelas XII IPA 1 SMA Negeri 1 Lawa dengan jumlah siswa sebanyak 31 orang. Hasil penelitian menunjukan bahwa hasil belajar siswa dalam pelaksanaan siklus I didapat nilai rata-rata 68,39 , dengan ketuntasan belajar siswa secara klasikal adalah $74 \%$ dimana siswa yang tuntas sebanyak 21 orang dan yang tidak tuntas sebanyak 10 orang dari 31 jumlah siswa yang mengikuti tes evaluasi siklus I aktivitas siswa dalam pelaksanaan siklus II mencapai $71,53 \%$ dan sedangkan aktivitas guru juga mengalami peningkatan yaitu $87,50 \%$. Ketuntasan hasil belajar siswa pada siklus II mencapai 87,10\% dari 31 siswa yang mengikuti tes, jumlah siswa yang tuntas sebanyak 27 orang dan yang tidak tuntas ada 4 orang. Hal ini menunjukkan bahwa setiap siklusnya siswa mengalami peningkatan baik dalam hal hasil belajar maupun aktivitas siswa yang ditandai dengan meningkatnya nilai rata-rata siswa dan ketuntasan dalam pembelajaran dan meningkatnya aktivitas siswa dalam kegiatan belajar mengajar.
\end{abstract}

Kata Kunci: Pembelajaran Kontekstual Tipe CTL, Aktivitas Belajar, Hasil Belajar

PENDAHULUAN

Proses pembelajaran yang konvensional guru sangat mendominasi proses pembelajaran, sehingga siswa menjadi pasif dalam mengikuti kegiatan pembelajaran. Hal ini yang menyebabkan siswa takut mengungkapkan pendapatnya, ideidenya karena siswa menganggapguru menakutkan. Proses pembelajaran yang terjadi di SMA Negeri 1 Lawa saat ini pun masih menggunakan metode 
konvensional. Hal ini pula yang menyebabkan mereka bosan mengikuti proses pembelajaran yang diterapkan. Tanya jawab yang telah saya lakukan dengan beberapa guru mata pelajaran lain dan beberapa siswa ,bahwasanya siswa sangat sulit atau sangat kurang dalam pelajaran PKn jadi nilai yang didapat masih kurang dari nilai maksimal.

Sebelum melakukan proses belajar mengajar seorang guru harus menentukan suatu pendekatan yang akan digunakan agar tujuan pembelajaran yang telah disusun dapat tercapai. Pemilihan suatu pendekatan tentu harus disesuaikan dengan tujuan pembelajaran dan sifat materi yang akan menjadi objek pembelajaran. Pembelajaran kontekstual mengajak siswa belajar sambil bekerja dalam mempelajari ekosistem yang mereka lakukan di sekolah maupun yang dilakukan di luar sekolah. Pembelajaran yang mengajak siswa untuk belajar sambil bekerja akan mewujudkan pembelajaran yang bermakna bagi siswa. Pembelajaran yang bermakna akan membuat siswa merasa bahwa apa yang mereka lakukan tidak sia-sia dan mereka mempunyai peran di dalam kegiatan pembelajaran.

Maka permasalahan yang muncul adalah bagaimana upaya guru untuk meningkatkan hasil belajar siswa dengan pendekatan yang tepat. Salah satu pendekatan pembelajaran yang dapat meningkatkan kreativitas siswa dalah pendekatan kontekstual. Dengan pendekatan kontekstual, siswa diarahkan untuk mengaitkan antara materi yang diajarkan dengan situasi nyata siswa dan mendorong siswa membuat hubungan antara pengetahuan yang dimilikinya dengan kehidupan mereka sebagai anggota keluarga dan masyarakat. Melihat hal tersebut, maka perlu dilakukan suatu penelitian untuk menemukan sebuah alternative pemecahan masalah dalam upaya meningkatkan kualitas pembelajaran gunameningkatkan prestasi belajar siswa.

Contextual Teaching and Learning (CTL) adalah suatu strategi pembelajaran yang menekankan kepada proses keterlibatan siswa secara penuh untuk dapat menemukan materi yang dipelajari dan menghubungkannya dengan situasi kehidupan nyata sehingga mendorong siswa untuk dapat menerapkannya dalam kehidupan mereka. Pada dasarnya saat ini kondisi yang ada di sekolahan kurang begitu maju dalam kegiatan belajar mengajar, pada umumnya guru hanya mengajar sesuai dengan kurikulum yang ada tanpa ada variasi apa pun. permasalahan yang terjadi saat ini adalah kurang begitu bervariasi dalam menyampaikan materi sehingga anak cepat bosan sehingga hasil belajar siswa kurang maksimal, untuk itu saya mencoba menyampaikan materi yang akan saya lakukan nanti yaitu dengan member sedikit variasi agar siswa tidak begitu jenuh dalam menerima materi yang akan disampaikan dengan cara melibatkan langsung siswa dalam materi yang akan disampaikan, dengan cara pendekatan CTL ini diharapkan siswa bisa lebih aktif dalam belajar karena pendekatan CTL itu sendiri adalah suatu strategi pembelajaran yang menekankan kepada proses keterlibatan siswa secara penuh untuk dapat menemukan materi yang dipelajari dan menghubungkannya dengan situasi kehidupannya sehingga mendorong siswa untuk dapat menerapkannya dalam kehidupan mereka. 
Tapi pada kenyataannya yang ada di sekolah berbeda dengan teori yang ada, bahwa siswa banyak yang monoton pada materi yang disampaikan oleh guru sehingga kondisi dalam pembelajaran tidak bisa hidup karena siswa fakum dalam belajar.Untuk itu saya mencoba menerapkan pendekatan CTL dalam pembelajaran yang nantinya akan saya lakukan dalam penelitian.

Berdasarkan uraian di atas, peneliti yang juga selaku guru PKn di kelas XII IPA.1 tertarik untuk melakukan penelitian bekerja sama dengan guru PKn lainnya yaitu Ibu guru Salni Yanti,S.Pd sebagai kolaborator/observer dalam menerapkan pendekatan CTL melalui Penelitian Tindakan Kelas (PTK) yang berjudul "Upaya meningkatkan aktivitas dan hasil belajar Siswa pada materi Pancasila Sebagai Idiologi Terbuka dengan menggunakan metode pendekatan CTL (Contextual Teaching and Learning) di kelas XII IPA.1 SMA Negeri 1 Lawa tahun Pelajaran 2016/2017.

\section{METODE PENELITIAN}

\section{Jenis dan Setting Penelitian}

Jenis Penelitian ini adalah Penelitian Tindakan Kelas yang disingkat PTK (Classroom Action Research).siswa kelas XII IPA 1 SMA Negeri 1 Lawa, yang berjumlah 31 siswa yang terdiri dari 12 siswa laki-laki dan 19 siswa perempuan.

\section{Rencana Tindakan}

Tahap Perencanaan
Kegiatan ini diawali dengan orientasi, yaitu studi pendahuluan sebelum tindakan penelitian dilaksanakan. Berdasarkan hal tersebut di atas maka disusunlah rencana tindakan yang hendak dilaksanakan berupa rencana pelaksanaan pembelajaran (RPP) selama proses pelaksanaan pembelajaran sosiologi dengan menggunakan model pembelajaran Kontekstual tipe CTL.

\section{Tahap Pelaksanaan Tindakan}

Tahap pelaksanaan tindakan yaitu melaksanakan skenario pembelajaran yang telah disusun sebelumnya pada perencanaan. Guru melaksanakan pembelajaran dengan menggunakan model pembelajaran Kontekstual (CTL).

\section{Observasi dan Evaluasi}

Pada tahap ini obsever mengobservasi segala tindakan atau aktivitas yang telah dilakukan oleh guru dengan menggunakan lembar observasi dalam proses pembelajaran $\mathrm{PKn}$ dengan menerapkan model pembelajaran Kontekstual tipe CTL. Pada setiap akhir tindakan diadakan tes untuk mengetahui peningkatan hasil belajar setiap siklus yang dilakukan guru.

\section{Tahap Refleksi}

Kegiatan yang dilakukan pada tahap ini, Peneliti melaksanakan diskusi dengan pengamat (observer) utuk merefleksi hasil observasi dan evaluasi yang dilakukan. Refleksi dilakukan untuk mengkaji hal-hal yang telah dicapai dan belum dicapai atau melihat apakah rencana telah terlaksana secara optimal dan perlu dilakukan perbaikan. Hasil refleksi digunakan untuk menetapkan 
langkah-langkah lebih lanjut pada siklus berikutnya.

Data tentang pelaksanaan pembelajaran akan dianalisis secara deskriptif berdasarkan hasil observasi dari observer. Sedangkan data kuantitatif akan dianalsis dengan melihat hasil tes pada setiap akhir tindakan. Artinya apabila setiap akhir tindakan secara klasikal belum mencapai $85 \%$ dari KKM maka akan dilanjutkan pada siklus berikutnya, sampai mencapai indikator kinerja yang telah ditetapkan.

\section{HASIL DAN PEMBAHASAN}

\section{Hasil Penelitian}

\section{Tindakan Siklus I}

\section{Perencanaan}

Pada taha pini, peneliti membuat instrumen dan perangkat pembelajaran yang mengacu pada penerapan model pembelajaran kontekstual yang akan digunakan dalam pelaksanaan tindakan.. Adapun hala-hal yang dilakukan pada tahap ini adalah membuat RPP, membuat LKS , membuat lembar observasi untuk guru dan siswa, menyediakan alat dan media pembelajaran, membuat jurnal refleksi diri, dan menyusun tes siklus I.

\section{Pelaksanaan tindakan}

Pelaksanaan tindakan pertemuan pertama guru-guru memulai pembelajaran dengan berdoa terlebih dahulu lalu mengabsen siswa, dan mempersiapkan materi ajar. Kemudian mengecek pengetahuan awal siswa dengan mengajukan beberapa pertanyaan yang berhubungan dengan materi yang akan diajarkan. Lalu memotivasi siswa agar lebih bersemangat untuk belajar, selanjutnya guru menyampaikan tujuan pembelajaran yang akan dicapai.

Pada kegiatan inti, sebelum masuk pada materi pembelajaran guru menggali pengetahuan awal siswa dengan melontarkan bebera pertanyaan'. Pengetahuan awal tersebut akan dijadikan acuan untuk menyelidikinya (Konstruktivisme).

Selanjutnya guru menjelaskan materi pembelajaran serta melontarkan pertanyaan yang bertujuan untuk memacu pemahaman siswa dengan menghubungkan antara materi dengan konteks keseharian siswa di lingkungannya (Questioning).

Kemudian dilanjutkan dengan kegiatan mengorganisasikan siswa membentuk kelompok yang terdiri dari 6 - 7 orang yang memiliki kemampuan akademik yang heterogen. Pembentukan kelompok yang heterogen dapat mengoptimalkan proses dan hasil belajar siswa, selanjutnya masingmasing kelompok diberi permasalahan yang harus mereka selesaikan. Penyelesaian masalah dilakukan dengan melakukan pengamatan dan mencari informasi sebanyak-banyaknya mengenai masalah yang harus mereka pecahkan. Dengan melakukan pengamatan apa yang mereka sering jumpai bahkan dilakukan dalam kehidupan nyatasehari-hari siswa. Setiap kelompok diberi kesempatan untuk mempresentasikan hasil simpulan sementara mereka.

Guru memperjelas pembelajaran dengan menyimpulkan hasil diskusi. Sebelum mengakhiri pembelajaran, guru menanyakan kepada siswa hal-hal yang belum dipahami serta hal yang 
dapat menggangu jalannya proses pembelajaran berikutnya (Reflection). Lalu mengumpulkan hasil diskusi kelompok siswa, dilanjutkan dengan menilai hasil kerja kelompok serta menentukan kelompok terbaik dalam diskusi kelompok dan tak lupa guru memberikan pujian kepada kelompok terbaik (Autentic Asessment).

Pada kegiatan akhir pembelajaran, guru bersama siswa menyimpulkan materi pembelajaran yang telah dipelajari. Lalu diakhiri dengan menyampaikan materi yang akan dipelajari pertemuan berikutnya.

\section{Pengamatan}

Selama proses pembelajaran melakukan pengamatan untuk mengetahui aktivitas guru dan siswa dalam pelaksanaan pembelajaran.

\section{Refleksi}

Membuat simpulan sementara terhadap pelaksanaan siklus I. Berdasarkan hasil pelaksanaan Siklus I, Bahwa. hasil belajar siswa dalam pelaksanaan siklus I didapat nilai rata-rata 68,39 , dengan ketuntasan belajar siswa secara klasikal adalah $67 \%$ dan, 74\% dimana siswa

yang tuntas sebanyak 21 orang dan yang tidak tuntas sebanyak 10 orang dari 31 jumlah siswa yang mengikuti tes evaluasi siklus I.

Sedangkan untuk aktivitas siswa pada siklus I diperoleh persentase sebanyak $56,69 \%$ atau kategori cukup baik. Peningkatan tersebut tidak lepas dari keseriusan peserta didik dalam mengikuti kegiatan pembelajaran. Terutama kerjasamanya dengan teman lain dalam kelompok untuk mengkonstruksi pengetahuannya untuk menemukan penyelesaian yang harus mereka selesaikan. Dalam proses penyelesaian masalah yang dihadapi, siswa mengeluarkan segala pengetahuannya untuk sharing antar teman dalam kelompok. Walaupun dalam siklus I ini siswa masih belum bisa secara maksimal dalam proses pembelajaran, terutama dalam hal mengeluarkan pendapatnya untuk menjawab pertanyaan dari guru maupun mengerjakan soal di depan (mendemonstrasikan hasil diskusi) karena masih takut salah atas penyelesaian yang mereka selesaikan.

Dengan demikian berdasarkan hasil dari pelaksanaan penelitian pada siklus I, guru berusaha melakukan perbaikan-perbaikan dengan pendekatan memotivasi agar siswa bisa percaya diri dalam mengeluarkan pendapatnya dan kemampuannya pada siklsu II.

Pada pelaksanaansiklus I, hasil dan aktivitas belajar dapat dilihat dalam tabel 1 berikut.

Tabel 1: Tabel hasil pengamatan siklus

\begin{tabular}{clc}
\multicolumn{2}{c}{ I } & \\
\hline No. & \multicolumn{1}{c}{ Indikator } & $\begin{array}{c}\text { Hasil } \\
\text { Pengamatan }\end{array}$ \\
\hline 1. & Aktivitas guru & $78,13 \%$ \\
\hline 2. & Aktivitassiswa & $56,69 \%$ \\
\hline 3. & Nilai rata-rata kelas & 68,39 \\
\hline 4. & Ketuntasanbelajarsiswa & $67,74 \%$ \\
\hline
\end{tabular}

\section{Tindakan Siklus II}

\section{Perencanaan}

Berdasarkan hasil observasi, evaluasi dan refleksi pada tindakan siklus I, maka peneliti bersama observer kembali merencanakan siklus II dengan harapan kekurangan dan kelemahan pada pelaksanaan siklus I dapat diperbaiki sehingga diharapkan tindakan siklus II 
mengalami penyempurnaan. Adapun hal-hal yang dilakukan pada tahap ini adalah meninjau kembali rancangan pembelajaran yang disiapkan untuk siklus II dengan melakukan revisi sesuai hasil siklus I.

\section{Pelaksanaan Tindakan}

Melaksanakan pembelajaran sesuai dengan RPP yang telahdisiapkan sesuai revisi berdasarkan evaluasi pada siklus 1. Langkahdalam pembelajarannya sama seperti pada siklus I. Dalam siklus IImembahas tentang sub materi ideologi tebuka, ideologi tertutup dan fungsi ideologi. Disini guru juga ikut berperan aktif dalam membimbing dan mengamati saat siswa belajar serta menjawab pertanyaanyang kira-kira siswa belum tahu guru bisa menjelaskan sekilas meskipun sebelumnya sudah dijelaskan.

Disini, siswa lebih dituntut lagi untuk mempresentasikan hasil diskusinya. Setiap kelompok mewakili satu anak maju untuk presentasi membahas hasil kerja kelompoknya. Ada beberapa anak yang mengajukan pertanyaan kepada setiap kelompok yang maju dan setiap pertanyaan dicatat guru untuk dibahas bersama-sama. Setelah semua kelompok sudah mempresentasikan, maka guru disini berperan aktif dalam menjelaskan sub materi ideologi tebuka, ideologi tertutup dan fungsi ideologi yang siswa presentasikan di depan kelas.

\section{Pengamatan}

Melakukan pengamatan yang sama pada seperti siklus I, dalam proses pembelajarannya guru bisa lebih tahu aktivitas siswa karenaguru ikut andil dalam peran diskusi siswa, guru juga melakukan evaluasi di siklus II serta mencatat keberhasilan dan hambatan yang dialami dalam proses pembelajaran pada pelakasaan siklus II.

\section{Refleksi}

Refleksi pada siklus II ini dilakukan untuk melakukan penyempurnaan metode pembelajaran dengan menggunakan pendekatan kontekstual (CTL) yang diharapkan dapat meningkatkan aktivitas siswa dalam proses pembelajaran dan hasil belajar.

Aktivitas belajar siswa pada siklus II lebih baik dibanding pada siklus I, hal ini dikarenakan siswa mulai terbiasa dalam pelaksanaan pembelajaran dengan pendekatan kontekstual. Disamping itusiswa mulai tumbuh kepercayaan diri dalam dirinya untuk bisa menyelesaikan masalah. Secara tidak langsung hal ini bisa membuatsiswa tidak takut lagi salah, dan tidak takut lagi untuk mengeluarkan pendapatnya untuk menyelesaikan masalah.

Aktivitas siswa dalam pelaksanaan siklus II mencapai 71,53\% dan sedangkan aktivitas guru juga mengalami peningkatan yaitu $87,50 \%$. Ketuntasan hasil belajar siswa pada siklus II mencapai $87,10 \%$ dari 31 siswa yang mengikuti tes, jumlah siswa yang tuntas sebanyak 27 orang dan yang tidak tuntas ada 4orang. Hal ini menunjukkan bahwa setiap siklusnya siswa mengalami peningkatan baik dalam hal hasil belajar maupun aktivitas siswa yang ditandai dengan meningkatnya nilai rata-rata siswa dan ketuntasan dalam pembelajaran dan meningkatnya aktivitas siswa dalam kegiatan belajar mengajar.

Pada pelaksanaan siklus II, hasil dan aktivitas belajar dapat dilihat dalam tabel 2 berikut. 
Tabel 2. Hasil dan Aktivitas Belajar

\begin{tabular}{lll}
\hline No. & \multicolumn{1}{c}{ Indikator } & \multicolumn{1}{c}{$\begin{array}{c}\text { Hasil } \\
\text { Pengamatan }\end{array}$} \\
\hline 1. & Aktivitas guru & $87,50 \%$ \\
\hline 2. & Aktivitas siswa & $71,53 \%$ \\
\hline 3. & Nilai rata-rata kelas & 75,10 \\
\hline 4. & $\begin{array}{l}\text { Ketuntasan belajar } \\
\text { siswa }\end{array}$ & $87,10 \%$ \\
\hline
\end{tabular}

\section{Pembahasan}

Penelitian ini adalah Penelitian Tindakan Kelas (PTK), di mana guru yang bertindak sebagai peneliti yang juga mengajar di kelas XII yang diberi tindakan dibantu oleh seorang teman sejawat yang bertindak sebagai kolaborator atau observer yang bertugas mengamati aktivitas guru dan siswa selama proses pembelajaran dengan pendekatan kontekstual (CTL) berlangsung.

Penelitian dilaksanakan di kelas XII IPA.1 semester 1 tahun pelajaran 2016/2017. Penelitian ini meliputi perencanaan, pelaksanaan tindakan, observasi dan refleksi. Kegiatan penelitian ini dilaksanakan dalam dua siklus yaitu siklus I dan siklus II. Sebelum dilakukan tindakan pra siklus dilakukan untuk mengetahui pelaksanaan pembelajaran yang belum menggunakan pendekatan kontekstual

Pada siklus I, Guru menggunakan pendekatan kontekstual (CTL) didapatkan hasil belajar siswa dengan nilai rata-rata $68,39 \%$ dan ketuntasan belajar secara klasikal adalah $67,74 \%$. Adapun aktivitas siswa pada siklus I adalah 56,69 atau kategori cukup aktif, namun belum mencapai Indikator. Oleh karena itu tindakan dilanjutkan ke siklus II, di mana hasil belajar siswa pada siklus 2 dengan nilai rata-rata 75,10 , dan ketuntasan belajar secara klasikal adalah $87,10 \%$. Selanjutnya aktivitas siswa pada siklus 2 adalah 71,53\% atau berkategori aktif. Dengan demikian pembelajaran yang berlangsung pada siklus II ini sudah dianggap berhasil karena sudah mencapai indikator.

\section{KESIMPULAN}

\section{Kesimpulan}

Penelitian ini dilaksanakan pada semester ganjil tahun pelajaran 20162017 di kelas XII IPA 1 SMA Negeri 1 Lawa dengan jumlah siswa sebanyak 31 orang. Hasil penelitian menunjukan bahwa hasil belajar siswa dalam pelaksanaan siklus I didapat nilai ratarata 68,39, dengan ketuntasan belajar siswa secara klasikal adalah $74 \%$ diman asiswa yang tuntas sebanyak 21 orang dan yang tidaktuntas sebanyak 10 orang dari 31 jumlah siswa yang mengikuti tes evaluasi siklus Iaktivitas siswa dalam pelaksanaan siklus II mencapai 71,53 \% dan sedangkan aktivitas guru juga mengalami peningkatan yaitu $87,50 \%$. Ketuntasan hasil belajar siswa pada siklus II mencapai $87,10 \%$ dari 31 siswa yang mengikuti tes, jumlah siswa yang tuntas sebanyak 27 orang dan yang tidak tuntas ada 4 orang.Hal ini menunjukkan bahwa setiap siklusnya siswa mengalami peningkatan baik dalam hal hasil belajar maupun aktivitas siswa yang ditandai dengan meningkatnya nilai rata-rata siswa dan ketuntasan dalam pembelajaran dan meningkatnya aktivitas siswa dalam kegiatan belajar mengajar. 


\section{DAFTAR PUSTAKA}

Departemen Pendidikan Nasional. 2002. Pendekatan Kontekstual (ContextualTeachingand

Learning (CTL)), (Jakarta: Depdiknas).

Nana Sudjana. 2008.Dasar-Dasar Proses Belajar Mengajar, (Bandung: Sinar Baru Algensindo).

Oemar Hamalik. 2008. Proses Belajar Mengajar. Jakarta: Bumi Aksara.

Slameto. 1995. Belajardan Faktorfaktor yang Mempengaruhinya. Jakarta: Rineka Cipta.

Sugiyono. 2002. Metode Penelitian Pendidikan:Pendekatan Kuantit atif, Kualitatif danR \& B. Bandung: Alfabeta.

Syaiful Sagala. 2003. Konsep dan Makna Pembelajaran. Bandung: Alfabeta.

Suprihatiningrum, J. 2013. Strategi Pembelajaran: Teori dan Aplikasi. Jogjakarta: Ar-Ruzz Media.

Winasanjaya. $2006 . \quad$ Strategi pembelajaran

berorientasi standar proses pendidikan. Jakarta: Kencana.

Wiriaatmadja, R, (2012). Metode Penelitian Tindakan Kelas, (Bandung: PT. Remaja Rosdakarya)
Yudhistira, D, (2013). Menulis Penelitian Tindakan Kelas Yang Apik (Asli PerluIlmiah Konsisten), (Jakarta: PT. Gramedia Widiasarana Indonesia) 